\title{
Associated or Concomitant Diseases Influence Significantly the Health-Sickness Concept in Celiacs
}

\author{
Eduardo Cueto Rúa, Maria Teresita Gonzalez Villar, Ricardo Wright, Claudia Losada Gómez, \\ Karol Martínez, María Arregui, Luciana Guzmán, Cecilia Zubiri, Viviana Bernedo, Anabella Zosi, \\ Lorena Menéndez, Lucas Ruiz, Leopoldo Mancinelli, María Urrutia, Ricardo Drut*
}

School of Medical Sciences, La Plata National University, La Plata, Argentina

Email: *ricardodrut@yahoo.com

How to cite this paper: Cueto Rúa, E., Villar, M.T.G., Wright, R., Losada Gómez, C., Martínez, K., Arregui, M., Guzmán, L., Zubiri, C., Bernedo, V., Zosi, A., Menéndez, L., Ruiz, L., Mancinelli, L., Urrutia, M. and Drut, R. (2017) Associated or Concomitant Diseases Influence Significantly the HealthSickness Concept in Celiacs. Open Journal of Epidemiology, 7, 139-158. https://doi.org/10.4236/ojepi.2017.72013

Received: March 17, 2017

Accepted: May 12, 2017

Published: May 15, 2017

Copyright $\odot 2017$ by authors and Scientific Research Publishing Inc. This work is licensed under the Creative Commons Attribution International License (CC BY 4.0).

http://creativecommons.org/licenses/by/4.0/

\begin{abstract}
It is well-known that feeling to be a healthy or sick person most probably results from the mind than from the body. We all know healthy people who feel sick and vice versa. We were interested in the health and sickness feeling of celiac people, their autorating of these feelings and its conditioning factors as well as their expectations. In this paper we present the results of an inquiry to evaluate these situations. We performed a descriptive, transversal and prospective study for 2 years to groups of celiacs and their families. They received a closed inquiry to be completed before the beginning of the talk. The inquiry included personal data and the co-existence of associated or concomitant (AoC) diseases. Most of the sample's patients felt to be a healthy person $(86.8 \%)$. Mothers see their children as healthy and the auto rated criteria is significantly better than the adult celiac person (" $t$ " $=-6.024(p=0.000))$. AoC diseases influenced negatively in the feeling of being healthy and strongly decreased the autorating. Longer time passed on treatment reflects an increase feeling of health and of the autorating. In people with AoC diseases and who feel sick, the increased time of treatment did not show significant differences. People with "gluten sensitivity" felt sicker and auto rated themselves with a lower number than celiacs. Many pediatric gastroenterologists notice that the newly agreed definition of celiac disease, referring it as "autoimmune, chronic, incurable, and multisystemic", results in a very negative character of the condition which might compromise the future labour of this people as well as their admittance to different health insurance systems.
\end{abstract}

\section{Keywords}

Associated Conditions, Celiac Disease, Feeling, Gluten-Free Diet, Gluten Intolerance, Quality of Life, Health/Sickness, Pain, Self-Qualification 


\section{Introduction}

We all know that the feeling of being health or sick most probably has to do with the "soul" condition than with the body condition, and we conceive the soul as the psychic, the mind and the own conscience or the conscience of being. We all know healthy people who feel sick and sick people who feel healthy. We also know that disease as well as the definitions of it may produce a positive or negative impact in the people and accordingly, in their personal, social and labour future. We were interested in the health and sickness feeling of celiac and gluten-sensitive people and their autorating of these sensations and their conditioning circumstances. At the same time, we want to know their personal desires and social expectation. In this paper we present the results of an inquiry performed in order to evaluate these situations.

\section{Material and Methods}

We performed a descriptive, transversal and prospective study from December 2014 to December 2016 to groups of celiacs and relatives assisting to informative and adjournment sessions on this condition. They received a closed inquiry that needed to be fulfilled before the talk. All had to reply by themselves. The inquiry included a declaration depicting if the person was celiac, gluten-sensitive or a relative.

The inquiry included age and gender, site of residence (city, province, country) and instruction level. Also how the diagnosis was reached indicating if it included clinical features consistent with celiac disease, serology, endoscopy, biopsies and genetic study. The person had to indicate if he/she felt healthy or sick and the autorating (qualification) of this feeling from 0 to 10 points. We also asked about the existence or not of other associated or concomitant (AoC) conditions, and if any of these generated any pain.

The inquiry included: A) The weekly frequency of consuming of different types of foods offering as possible answer the following numbers: never: 0 , once a week: 1 . Every after day: 4 . All days: 7 . Morning and afternoon: 14. B) The special desire of one and only of these: 1) sandwich, 2) pizza, 3) pasty, 4) biscuit, 5) beer, 6) bread, 7) nothing. C) What they expected from people, with 3 possible answers: 1) respect, comprehension, tolerance, 2) attention or help, 3) nothing. D) What they expected from the state, social insurance and health coverings due to the condition of celiac person, with 4 possible answers: 1) money, 2) coverings and medical assistance, 3) involvement and responsibility, and 4) nothing. E) Lastly, they were asked if they preferred money for health to be expended providing them with "special flours" or spending it on running exams for possible celiac condition in relatives.

The statistical analysis was done using the Student " $\mathrm{t}$ " test for the comparison of the mean values. The ANOVA test was used when there were more than two mean values to be compared. When there were no significant differences the analysis was carried out with a test of minimal significant differences. The Square Chi test and the Proportional differences tests were used for the analysis 
of the definitive variables.

\section{Results}

There were 1052 inquiries 738 (70.15\%) of which resulted from celiacs. The relatives of the celiac person were: mother 274 (26.05\%), husband/wife 24 (2.28\%) and grandparent $16(1.52 \%) ; 940(89.3 \%)$ were women and $111(10.7 \%)$ men. Mean age was $39.6 \pm 14.7$ years.

\section{Site of residence}

All the inquiries were done in Argentina. People resided in the following provinces: Buenos Aires 60.4\%; Buenos Aires City 12.5\%; San Juan 6.7\%; Chubut 6.3\%; Tierra del Fuego 3.5\%; Misiones 2.7\%; Córdoba 1,.\%; Santa Fe 1\%. The remaining were from Tucumán, Entre Ríos, Neuquén, Salta, Mendoza, Chaco, La Rioja, Santiago del Estero y La Pampa (5,5\%). Participating people came from 170 cities as follows (The more numerous): Buenos Aires City 132, Merlo 47, San Juan 47, Comodoro Rivadavia 42, Trenque Lauquen 38, Miramar 33, San Nicolás 33, Bragado 29, La Plata 25, Posadas 23, Río Grande 22, Berisso 20, Príngles 20, Carlos Casares 19, Navarro 18, Berazategui 15, Ushuaia 14, San Cayetano 13, Cañuelas 12, Neuquén 11, Mar del Plata 11, Lobería 11, and Lanús 10.

\section{Instruction level}

This was answered by 1003 people (49 did not answer). Primary school 136 (136\%), secondary school $352(35.1 \%)$, tertiary school 252 (25.1\%) and university $263(26.2 \%)$.

$\underline{\text { Time on gluten-free diet }}$

\begin{tabular}{ccc}
\hline Time on gluten-free diet & $\mathrm{n}$ & $\%$ \\
\hline Less than 12 months & 196 & $18.6 \%$ \\
$\mathbf{1}$ year & 132 & $12.5 \%$ \\
$\mathbf{2}$ years & 132 & $12.5 \%$ \\
$\mathbf{3}$ years & 95 & $9.0 \%$ \\
$\mathbf{4}$ years & 68 & $6.5 \%$ \\
$\mathbf{5}$ years & 87 & $8.3 \%$ \\
$\mathbf{6}$ years & 46 & $4.4 \%$ \\
$\mathbf{7}$ years & 41 & $3.9 \%$ \\
$\mathbf{8}$ years & 44 & $4.2 \%$ \\
$\mathbf{9}$ years & 25 & $2.4 \%$ \\
$\mathbf{1 0}$ or more years: & 186 & $17.7 \%$ \\
\hline
\end{tabular}

Diagnosis of the condition \%).

\begin{tabular}{|c|c|c|}
\hline Diagnosis of the condition $\left(^{*}\right)$ & $\mathbf{n}$ & $\%$ \\
\hline Clinical diagnosis only & 8 & 0.8 \\
\hline Clinical and serology & 36 & 3.5 \\
\hline
\end{tabular}




\section{Continued}

\begin{tabular}{ccc}
\hline Clinical, serology and endoscopy & 15 & 1.5 \\
Clinical, serology and genetics & 7 & 0.7 \\
Clinical, serology, endoscopy and biopsy: & 910 & 88.3 \\
Clinical, serology, endoscopy, biopsy and genetics: & 54 & 5.2 \\
\hline
\end{tabular}

$\left.{ }^{*}\right)$ These diagnosis were not verified and all were assumed as certain.

\section{Health/disease feeling}

\begin{tabular}{ccc}
\hline Health/disease feeling & $\mathbf{n}$ & $\%$ \\
\hline Felt healthy & 913 & $(86.8 \%)$. \\
Felt sick & 139 & $(13.2 \%)$. \\
\hline
\end{tabular}

\section{Autorating}

\begin{tabular}{ccc}
\hline Autorating & $\mathbf{n}$ & $\%$ \\
\hline With 10 points: & 337 & 35.8 \\
With 9 & 159 & 15.1 \\
With 8 & 201 & 19.1 \\
With 7 & 134 & 12.7 \\
With 6 & 48 & 4.6 \\
With 5 & 39 & 3.7 \\
With 4 & 51 & 4.8 \\
With 3 & 23 & 2.2 \\
With 2 & 11 & 1 \\
With 1 & 8 & 0.8 \\
With 0: & 1 & 0.1 \\
\hline
\end{tabular}

The overall mean was $8.11 \pm 2.08$.

AoC conditions

\begin{tabular}{ccc}
\hline AoC conditions & $\mathbf{n}$ & $\%$ \\
\hline Celiacs without AoC: & 652 & 62.1 \\
With 1 AoC & 283 & 26.9 \\
With 2 & 81 & 7.7 \\
With 3 & 27 & 2.6 \\
With 4 & 8 & 0.8 \\
\hline & & \\
\hline AoC conditions producing pain, & 97 & 9.2
\end{tabular}


Foods: frequency in days per week

\begin{tabular}{lc}
\hline \multicolumn{1}{c}{ Foods } & frequency in days per week \\
\hline $\mathbf{1}^{\circ}$ Milk derived: & $7.07 \pm 4.38$ \\
$\mathbf{2}^{\circ}$ Biscuits & $6.88 \pm 4.20$ \\
$\mathbf{3}^{\circ}$ Oils & $6.09 \pm 3.33$. \\
$\mathbf{4}^{\circ}$ Vegetable & $5.93 \pm 3.61$ \\
$\mathbf{5}^{\circ}$ Meats & $5.70 \pm 2.69$ \\
$\mathbf{6}^{\circ}$ Fruits & $5.50 \pm 4.01$ \\
$\mathbf{7}^{\circ}$ Maize rice & $5.33 \pm 3.30$ \\
$\mathbf{8}^{\circ}$ Sweeties & $4.50 \pm 3.69$ \\
$\mathbf{9}^{\circ}$ Sodas & $4.27 \pm 4.24$ \\
$\mathbf{1 0}^{\circ}$ Cake & $2.47 \pm 2,90$ \\
$\mathbf{1 1}^{\circ}$ Cold meats & $1.74 \pm 2.45$ \\
$\mathbf{1 2}^{\circ}$ Legumes & $1.55 \pm 2.16$ \\
\hline
\end{tabular}

\section{Personal wish}

\begin{tabular}{lc}
\hline \multicolumn{1}{c}{ Personal wish } & n and (\%) \\
\hline $1^{\circ}$ Sandwich & $375(35.6)$ \\
$2^{\circ}$ Bread & $180(17.1)$ \\
$3^{\circ}$ Biscuits & $167(15.9)$ \\
$4^{\circ}$ Pizza & $157(14.9)$ \\
$5^{\circ}$ Pasty & $82(7.8)$ \\
$6^{\circ}$ Beer & $63(0.6)$ \\
$7^{\circ}$ Nothing & $28(2.7)$ \\
\hline
\end{tabular}

Expectation of people

\begin{tabular}{ll}
\hline \multicolumn{1}{c}{ Expectation of people } & n and (\%) \\
\hline $1^{\bullet}$ Respect, comprehension, tolerance: & $732(69.8)$. \\
$2^{\circ}$ Attention or help: & $186(17.7)$ \\
$3^{\circ}$ Nothing & $130(12.4)$ \\
\hline
\end{tabular}

Expectation of the State, Social insurance and Health coverings

\begin{tabular}{cc}
\hline Expectation of the State, Social insurance and Health coverings & $\mathbf{n}$ and (\%) \\
\hline $1^{\circ}$ Involvement and responsibility & $477(45.3)$ \\
$2^{\circ}$ Coverings and medical assistance & $353(33.6)$ \\
$3^{\circ}$ Economic help & $169(16.1)$ \\
$4^{\circ}$ Nothing & $53(5)$ \\
\hline
\end{tabular}

Money spend in health.

\begin{tabular}{lc}
\hline \multicolumn{1}{c}{ Money spend in health } & $\mathbf{n}$ and (\%) \\
\hline $1^{\circ}$ Studies in relatives & $534(56.3)$ \\
$2^{\circ}$ Flours & $364(38.4)$ \\
$3^{\circ}$ No answer & $51(5.4)$ \\
\hline
\end{tabular}

(The first 103 participants did not have this question due to a later redesign of the inquiry). 


\section{RESULTS CROSSING VARIABLES}

\section{Feeling and autorating}

Choosing 913 (86.8\%) people feeling healthy the mean autorating was $8.71 \pm$ 1.30 points while in 139 (13.2\%) people feeling sick the autorating was $4.14 \pm$ 1.51 points.

\begin{tabular}{ccc}
\hline Feeling & $\mathbf{n}(\%)$ & autorating \\
\hline Healthy & $913(86.8 \%)$ & $8.71 \pm 1.30$ \\
Sick & $139(13.2 \%)$ & $4.14 \pm 1.51$ \\
\hline
\end{tabular}

Of 992 celiacs $871(87.8 \%)$ felt healthy and 121 (12.2\%) sick; autorating $8.17 \pm$ 2.07. In 60 gluten-sensitive 42 (70\%) felt healthy and 18 (30\%) sick; autorating $7.15 \pm 2.12$.

\begin{tabular}{ccc}
\hline Feeling & celiacs & sensitive \\
\hline Healthy & $871(87.8 \%)$ & $42(70 \%)$ \\
Sick & $121(12.2 \%)$ & $18(30 \%)$ \\
autorating & $8.17 \pm 2.07$ & $7.15 \pm 2.12$ \\
\hline
\end{tabular}

When the two conditions are compared it shows that the feeling of "healthy/ sick" the Chi-square $=14.12$; $(\mathrm{p}=0.000)$ results indicate a highly significant dependence of the compared variables. Same happens with the comparison of the "autorating" $(\mathrm{t}=3.701 \mathrm{p}=0.000)$. Conclusion: celiac people feel significantly and proportionally more healthy and self qualify better than the "gluten-sensitive" ones.

Feeling and auto rating in the larger groups

Two groups were selected: celiac people, $\mathrm{n}=738(70.2 \%)$ and mothers of a celiac $\mathrm{n}=274(26 \%)$. In the first group $623(84.4 \%)$ felt healthy and $115(15.6 \%)$ sick. In the second 253 (92.3\%) felt healthy and 21 (7.7\%) sick. The Chi-square = 10.10 ( $\mathrm{p}=0.001$ ) demonstrates the association between la feeling of health and the mother's perception.

\begin{tabular}{cccc}
\hline healthy & sano & sick & autorating \\
\hline Celiac people $\mathbf{n}=\mathbf{7 3 8 ( 7 0 . 2 \% )}$ & $623(84.4 \%)$ & $115(15.6 \%)$ & $7.86 \pm 2.17$ \\
Mothers of a celiac $\mathbf{n}=\mathbf{2 7 4}(\mathbf{2 6 \% )}$. & $253(92.3 \%)$ & $21(7.7 \%)$ & $8.74 \pm 1.75$. \\
\hline
\end{tabular}

In the autorating the celíacs (738) mean was $7.86 \pm 2.17$ and the mother's group (274) was $8.74 \pm 1.75$. The Student test was " $\mathrm{t} "=-6.024(\mathrm{p}=0.000)$ resulting in a highly significant difference. Conclusion: mothers of celiac children felt them significantly and proportionally more healthy and auto rated than adult celiac people.

Autorating and AoC conditions

The autorating of celiac people was 8.48. In those who besides had also another AoC condition: 7.87; with 2 AoC: 7.15; with 3 AoC: 6.11, and with 4 
AoC: 4.25 .

\begin{tabular}{cc}
\hline Autorating and AoC conditions & Autorating \\
\hline Celiac people & $8.48 \pm 1.84$ \\
Another AoC condition: & $7.87 \pm 2.17$ \\
With 2 AoC & $7.15 \pm 2.25$ \\
With 3 AoC & $6.11 \pm 2.53$ \\
With 4 AoC & $4.25 \pm 3.93$
\end{tabular}

When comparing the rating of the feelings of celiacs with that who present done or more $\mathrm{AoC}$ conditions the difference was highly significant $(\mathrm{p}=0.000)$. When comparing celiacs with or without $1 \mathrm{AoC}$ condition there was a significant difference, while those having 1 and 2 AoC condition did not present a significant difference $(p=0.09)$; there was a difference between 2 and 3 conditions ( $p=$ $0.04)$ while there was not between 3 and 4 AoC conditions $(p=0.06)$. Conclusion: AoC conditions strongly influence the healthy/sick feeling and the autorating. (Table 1).

Autorating of celiacs without AoC condition vs celiacs with hypothyroidism only

In this comparison there was no significant difference $(\mathrm{p}=0.227)$ (Table 2). Conclusion: the hypothyroidism as the one and only associated condition does

Table 1. Feeling of Health-Sickness, qualification of celiacs and AoC conditions.

\begin{tabular}{ccccc}
\hline Variable & $\mathrm{n}$ & Healthy & Sick & Qualification \\
\hline 0 AoC & 652 & $599(91.9 \%)$ & $53(8.1 \%)$ & $8.48 \pm 1.84$ \\
1 AoC & 283 & $241(85.2 \%)$ & $42(14.8 \%)$ & $7.87 \pm 2.17$ \\
2 AoC & 81 & $58(71.6 \%)$ & $23(28.4 \%)$ & $7.15 \pm 2.22$ \\
3 AoC & 27 & $14(51.8 \%)$ & $13(48.1 \%)$ & $6.41 \pm 2.53$ \\
4 AoC & 8 & $1(12.5 \%)$ & $7(87.5 \%)$ & $4.25 \pm 1.98$ \\
\hline
\end{tabular}

The Chi-square test $=154.01(\mathrm{p}=0.0000)$ shows a highly significant dependence between the feeling perception and the increasing number of AoC conditions. The ANOVA test for the meaning self qualification for each group was $\mathrm{F}=21.41(\mathrm{p}=0.000)$.

Table 2. Impact of 1 AoC condition: "Hypothyroidism" vs "Not Hypothyroidism" or "Diabetes".

\begin{tabular}{ccccc}
\hline Celiacs with & $\mathrm{n}$ & Healthy & Sick & Qualification \\
\hline Hypothyroidism only & 217 & $115(90.6 \%)$ & $12(9.41 \%)$ & $8.28 \pm 2.13$ \\
One Not Hypothyroidism & 162 & $132(81.5 \%)$ & $30(18.5 \%)$ & $7.57 \pm 2.13$ \\
One (Diabetes) & 16 & $12(75.0 \%)$ & $4(25.0 \%)$ & $7.31 \pm 2.30$ \\
\hline
\end{tabular}

The Variance Analysis test showed to be $\mathrm{F}=5.60(\mathrm{p}=0.004)$ as related to autorating. The hypothyroidism only Group show highly significant differences with the other two groups. However, there are not between those having only one AoC condition. Conclusion: one AoC condition (not hypothyroidism) strongly impact in the healthy/sick relationship and in the autorating. 
not influence the healthy/sick feeling and the autorating when compared with celiac only people.

Autorating of celiacs without AoC condition vs celiacs with one, not hypothyroidism

In this comparison there was a highly significant difference $(\mathrm{p}=0.007)(\mathrm{Table}$ 2).

\section{Frequency and quality of $\mathrm{AoC}$ conditions}

\section{One and only AoC condition}

The order of prevalence by frequency was: hypothiroidism: 121; diabetes: 16; asthma 13; arthritis 10; allergy, arthrosis, epilepsy and osteoporosis: 8 each; chronic gastritis, hyperparathyroidism, fibromyalgia: 5 each; lactose intolerance, Down syndrome and colon Irritable: 3 each; thalassemia, psoriasis, herpetiformis dermatitis, autoimmune hepatitis, Asperger syndrome, beta thalassemia, multiple sclerosis, gastric ulcer, dyslipidemia: 2 each. Addison disease, achalasia, adenocarcinoma, cow milk protein allergy, scoliosis, cardiopathy, cirrhosis, collagenopathy, ulcerative colitis, constipation, immunodeficiency, rheumatism, rosacea, dolichocolon, endometriosis, hemophilia, hepatitis B, hepatopathy, hernia, Parkinson disease, cerebral palsy, uterine polyps, retinoblastoma, cardiac valvular lesion, 1 each.

\section{With two AoC conditions}

The order of prevalence of this pair was: hypothyroidism (HT) and diabetes: 9; HT and arthrosis: 5; HT and osteoporosis 4; HT and vitiligo: 3; HT and anemia, asthma, osteopenia or hypercholesterolemia, 2 each.

Of the following combinations there was only one case each: Allergy and otitis, anemia and migraine, anemia and osteopenia, arthrosis and diabetes, arthritis and hypertension, anemia and eczema, thyroid carcinoma and osteoporosis, alopecia and acne, diabetes and anemia, diverticular disease and arthrosis, epilepsy and hypoglycemia; scoliosis and fibromyalgia (FM), FM and diverticular disease, FM and asthma, FM and dyslipidemia, FM and thyroiditis, gastritis and ulcer, fatty liver and hypertension, hypertension and obesity, HT, epigastric pain, anxiety, arthritis, colonic carcinoma, carcinoma, hypercholesterolemia, dyspepsia, diverticular disease, Down syndrome, endometriosis, hepatitis, fatty liver, kidney lithiasis, migraine, obesity, prolactinoma, psoriasis, rosacea, Rohhadnet syndrome, Sjögren syndrome, thrombosis, one case each. Infections and chronic bronchitis-emphysema, obesity and rheumatism, osteoporosis (OP) and antiphospholipid syndrome, OP and anemia; OP and diabetes, OP and autoimmune hepatitis, Ovarian polycystic disease and metabolic syndrome, psoriasis and mental disease, rheumatism and vitiligo, rosacea and arthrosis, one case each.

With three AoC conditions

There is no repetition of a Group of three associated conditions. These were the following: anemia, alopecia, arrhythmias, arthritis, arthrosis, asthma, diverticular disease, depression, epilepsy, fibromyalgia, gastritis, renal failure, hyperparathyroidism, chronic hepatitis, osteopenia, osteoporosis, polyps, rheumatism, Sjögren disease, tendinitis. 


\section{With four AoC conditions}

There was no repetition of a Group of four. These were the conditions of the present group: abortions, anemias, arthrosis, diverticular disease, dyslipidemia, lactase deficiency, fibromyalgia, gastritis, hypothyroidism, fatty liver, hernia of the hiatus, hemophilia, nephropathy, psoriasis.

Feeling and autorating of celiac people with and without AoC condition and with and without pain (Table 3).

Table 3. Impact of AoC conditions, and of pain in the feeling of health and autorating in celiacs.

\begin{tabular}{ccccc}
\hline Variables & $\mathrm{N}$ & Healthy & Sick & Qualification \\
\hline Without AoC without pain & 643 & $590(91.8 \%)$ & $53(8.2 \%)$ & $8.47 \pm 1.85$ \\
With AoC without dolor & 407 & $267(85.9 \%)$ & $44(14.1 \%)$ & $7.90 \pm 2.15$ \\
With AoC and pain & 96 & $55(57.3 \%)$ & $41(42.7 \%)$ & $6.44 \pm 2.35$
\end{tabular}

The Chi-square value $=87.31(p=0.000)$ demonstrates that it depends from the feeling of being healthy or sick, the existence of associated conditions and the presence or not of pain. The ANOVA test to compare the means of the three groups resulted in a value of $\mathrm{F}=45.84(\mathrm{p}=0.000)$, indicating that statistically there are highly significant differences between the autorating and the presence or not of $\mathrm{AoC}$ conditions and the existence or not of pain. Applying a test for significant minimal differences it showed that there were highly significant differences between the three groups $(p=0.000)$. Conclusion: pain impacts significantly in the percentage of the relationship healthy/sick and in autorating.

In the following tables the personal appetite feeling (Table 4), what is expected from other people (Table 5), what is expected from the state and social insurance and Elath covering (Table 6), what to do with the subsidy (Table 7), age and level of instruction as influencing of what to do with the subsidy (Table 8). Up to Table 7 all the cases are analysed as if the person feels healthy/sick and the autorating. Table 9 shows the results of the analysis of the people coming to the talks on Celiac disease and to the commercial expositions. Table 10(a) shows the results of analysing the relationships of persons feeling healthy and the number of AoC while Table 10(b) shows the same but in persons feeling sick. Table 11 shows the impact of time of the feeling of being healthy/sick and the autorating. Table 12 and Table 13 shows the analysis of "time" in groups feeling healthy or sick.

Table 4. Personal food apetite and healthy/sick feeling, and autorating.

\begin{tabular}{ccccc}
\hline Personal & $\mathrm{N}$ & Healthy & Sick & Qualification \\
\hline Sandwich & 375 & $336(89.6 \%)$ & $39(10.4 \%)$ & $8.27 \pm 1.91$ \\
Pizza & 157 & $127(80.9 \%)$ & $30(19.1 \%)$ & $7.82 \pm 2.18$ \\
Pasty & 82 & $71(86.9 \%)$ & $11(13.4 \%)$ & $8.14 \pm 2.09$ \\
Biscuits & 167 & $149(89.2 \%)$ & $18(10.8 \%)$ & $8.20 \pm 2.20$ \\
Beer & 63 & $56(88.9 \%)$ & $7(11.1 \%)$ & $7.89 \pm 2.24$ \\
Bread & 180 & $150(83.3 \%)$ & $30(16.7 \%)$ & $7.99 \pm 2.15$ \\
Nothing & 28 & $24(85.7 \%)$ & $4(14.3 \%)$ & $8.21 \pm 2.27$ \\
\hline
\end{tabular}

The Chi-square value $=10.35(\mathrm{p}=0.11)$ shows that the feeling of health/sick does not depend of personal food appetites. The ANOVA test for autorating means showed a statistical value of $\mathrm{F}=1.16(\mathrm{p}=0.327)$ demonstrating that there were no differences between the compared means. Conclusion: the personal food preferences do not impact neither in the numbers of the healthy/sick feeling relationship nor in the autorating. 
Table 5. Expectations from the people.

\begin{tabular}{ccccc}
\hline & $\mathrm{N}$ & Healthy & Sick & Qualification \\
\hline Respect-Comprehension-Tolerance & 732 & $636(86.9 \%)$ & $96(13.1 \%)$ & $8.08 \pm 2.10$ \\
Attention-Help & 186 & $150(80.6 \%)$ & $36(19.4 \%)$ & $7.83 \pm 2.22$ \\
Nothing & 130 & $124(95.4 \%)$ & $6(4.6 \%)$ & $8.71 \pm 1.60$ \\
\hline
\end{tabular}

The Chi-square test $=14.54(\mathrm{p}=0.000)$ indicates that there is a dependence between the expectations of the people and the Feeling of health or sickness. Comparing the autorating with the ANOVA test the statistical value obtained of $\mathrm{F}=6.69(\mathrm{p}=0.001)$ was highly significant. The lowest autorating value was that of the Group demanding help, while the highest was that of the Group demanding nothing. Conclusion: there are significant differences between people expectations and the health/sick proportions as well as that of the autorating.

Table 6. Expectation of the state, social insurance and health coverings.

\begin{tabular}{ccccc}
\hline & $\mathrm{N}$ & Healthy & Sick & Qualification \\
\hline Money & $169(16.1 \%)$ & $138(81,7 \%)$ & $31(18.3 \%)$ & $7.70 \pm 2.25$ \\
Medical assistance & $353(33.6 \%)$ & $300(85.0 \%)$ & $53(15.0 \%)$ & $7.97 \pm 2.12$ \\
Involvement and responsibility & $477(45.3 \%)$ & $424(88.9 \%)$ & $53(11.1 \%)$ & $8.26 \pm 2.02$ \\
Nothing & $53(5 \%)$ & $51(96.2 \%)$ & $2(3.8 \%)$ & $9.0 \pm 1.43$ \\
\hline
\end{tabular}

The Chi-square test $=10.83(\mathrm{p}=0.016)$ allows to deduce that there is a relationship of is the expectations of the state, Social insurance and Health coverings and the feeling of health and sickness. Comparing the autorating with the same options the ANOVA test resulted in $\mathrm{F}=6.86(\mathrm{p}=0.000)$ which indicates a highly significant differences between the means. Conclusion: there are significant differences between the different expectations evaluated and the proportions of the healthy/sick and the autorating.

Table 7. What to do with the subsidy: flours of screening of relatives.

\begin{tabular}{ccccc}
\hline & $\mathrm{N}$ & Healthy & Sick & Qualification \\
\hline Special flours & 364 & $305(83.8 \%)$ & $59(16.2 \%)$ & $7.78 \pm 2.19$ \\
Screening of relatives & 464 & $401(82.2 \%)$ & $63(11.8 \%)$ & $8.23 \pm 2.00$ \\
\hline
\end{tabular}

The Chi-square test $=0.92(\mathrm{p}=0.336)$ allows to see that there is not a dependence of the feeling (health/sick) and that of the wish to do with the subsidy. Comparing the autorating means with the Student test the result is " $\mathrm{t}$ " $=-2.84(\mathrm{p}=0.012)$ indicating a highly significant difference between both. Conclusion: there are no significant differences in the proportions of healthy/sick in the destiny of the subsidy but indeed there is in the autorating.

Table 8. Age and instruction level as related to flour wish or relatives screening.

\begin{tabular}{cccc}
\hline & $\mathrm{N}$ & AGE & INSTRUCTION \\
\hline Special flours & 364 & $38.9 \pm 15.75$ & $2.59 \pm 1.02$ \\
Relatives screening & 534 & $39.7 \pm 31.41$ & $2.76 \pm 0.97$
\end{tabular}

The Student test of the means resulted " $\mathrm{t}$ " $=-0.45(\mathrm{p}=0.065)$ indicating that there were no significant differences in the ages while the value of $t=-2.52(p=0.001)$ showed a highly significant difference in the instruction level. Conclusion: there was not significant differences in the age of the groups but indeed there was in the instruction level.

Table 9. Assistance of people to informative talks and Expo celíaca 2016.

\begin{tabular}{cccc}
\hline Site of the inquiry & Healthy & Sick & Qualification \\
\hline Talks EACR ${ }^{*} 789$ & $673(85.3 \%)$ & $116(14.7 \%)$ & $8.05 \pm 2.14$ \\
Expo celíaca 263 & $240(91.3 \%)$ & $23(8.7 \%)$ & $8.28 \pm 190$ \\
\hline
\end{tabular}

*Eduardo Angel Cueto Rua. 
The Expo celiaca 2016 presented a higher percentage of healthy and and a better qualification. There was a significant difference in the feeling of healthy/sick and the place were the inquiry was done with a Chi-square test = 5.59 ( $\mathrm{p}=0.018$ ). However, when comparing the means of the qualification of both groups the " $\mathrm{t}$ " value was $=-1.55$ ( $\mathrm{p}=0.121$ ) indicating nod differences. Conclusion: people attending at Expo celiaca 2016 presented a significant difference in the healthy/sick relationship favouring feeling healthy, but not in the autorating.

Table 10. (a) People feeling healthy and number of AoC conditions self qualified with 8.71 points; (b) people feeling sick and number of AoC conditions auto rated with 4.14 points.

(a)

\begin{tabular}{ccc}
\hline AoC & $\mathrm{n}$ & $\%$ \\
\hline 0 & 599 & 65.6 \\
1 & 241 & 26.5 \\
2 & 58 & 6.4 \\
3 & 14 & 1.5 \\
4 & 1 & 0.1 \\
\hline
\end{tabular}

(b)

\begin{tabular}{ccc}
\hline AoC & $\mathrm{n}$ & $\%$ \\
\hline 0 & 53 & 38.4 \\
1 & 42 & 30.4 \\
2 & 23 & 16.7 \\
3 & 13 & 9.4 \\
4 & 7 & 5.1 \\
\hline
\end{tabular}

Comparing the results of tables A y B indicates that there is a dependence of the healthy/sick feeling and the number of AoC conditions. The Chi-square test was $=99.39(\mathrm{p}=0.000)$.

Table 11. Time with the condition of celiac and the healthy/sick feeling and autorating.

\begin{tabular}{ccccc}
\hline Time & Number of cases & Healthy & Sick & Qualification \\
\hline Months & 196 & $156(79.6 \%)$ & $40(20.4 \%)$ & $7.47 \pm 2.24$ \\
1 year & 132 & $110(83.3 \%)$ & $22(16.7 \%)$ & $7.84 \pm 2.34$ \\
2 to 5 years & 382 & $325(85.1 \%)$ & $57(14.9 \%)$ & $8.08 \pm 2.09$ \\
6 to 9 years & 156 & $147(94.2 \%)$ & $9(5.8 \%)$ & $8.54 \pm 1.82$ \\
10 years or more & 186 & $175(94.1 \%)$ & $11(5.9 \%)$ & $8.67 \pm 1.69$ \\
\hline
\end{tabular}

The Chi-square test $=27.37(\mathrm{p}=0.000)$ indicates a dependence between the time of the diagnosis of the celiac condition and the autoratings. The ANOVA test of the Qualification means was $F=10.55(p=0.000)$ indicating that there are highly significant differences. While analysing upon which categories were these differences it was notices that there are no differences in those of months of diagnosis group with the 1 year group but indeed with the other groups. Neither were differences between the 1 year Group and the 2 to 5 year group but indeed with the remaining two groups. The 2 to 5 years Group presented differences with the 6 to 9 years and the 10 and more years group. There were no differences between the two last groups. Conclusion: along the time the celiac people modified the healthy/sick relationship favouring healthy and highly significant improved their autorating. 
Table 12. Analysis of "time" in people auto rated as "healthy" and their autorating

\begin{tabular}{ccc}
\hline Time of diagnosis & N & Qualification \\
\hline Months & 156 & $8.34 \pm 1.50$ \\
1 year & 110 & $8.69 \pm 1.28$ \\
2 to 5 years & 325 & $8.73 \pm 1.37$ \\
6 to 9 years & 147 & $8.80 \pm 1.48$ \\
10 o more years & 175 & $8.96 \pm 1.91$ \\
\hline
\end{tabular}

The ANOVA test of the means resulted in $\mathrm{F}=3.65(\mathrm{p}=0.006)$, indicating significant differences. This difference is the result of the mean of the months of diagnosis Group which showed highly significant difference with all the other groups. The other means did not presented differences among them. Conclusion: people feeling healthy significantly increased their autorating along time.

Table 13. Analysis of "time" in people auto rated as "sick" and their autorating.

\begin{tabular}{ccc}
\hline Time of diagnosis & N & Qualification \\
\hline Months & 40 & $4.07 \pm 1.09$ \\
1 year & 22 & $3.59 \pm 1.76$ \\
2 to 5 years & 57 & $4.37 \pm 1.48$ \\
6 to 9 years & 9 & $4.33 \pm 1.80$ \\
10 or more years & 11 & $4.18 \pm 2.13$ \\
\hline
\end{tabular}

The ANOVA test of the means resulted in $\mathrm{F}=0.99(\mathrm{p}=0.416)$, indicating that there are no significant differences between them. Conclusion: people feeling sick did not presented a significant change in their autorating along time.

\section{Miscellanea}

Two antagonistic groups were selected.

"Mothers group": 141 people with a mean age of $38.7 \pm 10$ years who felt that her son had a autorating of 10 points and we looked for how many AoC conditions they had. Result: 112 (79.4\%) had none; 28 (19.9\%) had one; 1 (0.7\%) had 2. In summary: 29/141 (20.6\%) children presented AoC conditions.

"Celiac group": 41 people with a mean age of $39.1 \pm 15.6$ years felt that they had a autorating of 4 points and we loved for how many AoC conditions they had. Result: 16 (39\%) had none; 12 (29.3\%) had 1; 6 (14.6\%) had 2; 3 (7.3\%) had 3; 4 (9.8\%) had 4. In summary: 28 / 41 (61-0\%) adults had AoC conditions.

These groups did not present significant differences in the age $(\mathrm{p}=0.84)$, but they showed a significant difference in the proportion of the AoC conditions $(\mathrm{p}$ $=0.000)$. Conclusion: this indicates that the impact of the AoC conditions in both groups defined the feeling of healthy/sick condition.

\section{Conclusions}

1) Most of the people filling the inquiry felt healthy (86.8\%).

2) The autorating with " 10 points" reached $35 \%$.

3) Mothers saw their children more healthy and auto rated significantly better then celiac adults.

4) The AoC conditions influenced negatively in the feeling of being healthy.

5) The AoC conditions strongly decreased the autorating. 
6) The feeling of being sick and the autorating were directly related to the Lumber of AoC conditions.

7) Hypothyroidism as the one and only AoC condition did not influence neither the feeling of being healthy/sick not the autorating.

8) Diabetes as the one and only AoC condition negatively influenced the feeling of being healthy/sick and the autorating.

9) Pain when combined with AoC conditions negatively influenced in the feeling of being healthy/sick.

10) The increase in the time of treatment of the celiac condition globally increased the feeling of being healthy and the autorating.

11) In people feeling healthy the passing of time significantly improved their autorating.

12) In people feeling healthy there was a significant difference between those with few months of treatment with the rest, and in the later there were no differences between them.

13) In people feeling sick and with $\mathrm{AoC}$ conditions the pass of time did not show significant differences.

14) Milk products were the first in the list of consumed foods per week. Maize and rice were in the 7 th position and legumes were in the $12^{\text {th }}$ and last position.

15) In the personal selection most of the people selected "sandwich" made with appropriate flour (35.6\%).

16) In the demands to the state, social insurance and health coverings people selected "involvement and responsibility" (45.3\%), which together with medical covering reached $78.9 \%$.

17) Most of the people wanted that the destiny of health money should be spent in the screening of their relatives (56.3\%).

18) The person with "gluten sensitivity" felt more sick and auto rated with lower numbers than the celiac.

\section{Discussion}

In the experience on inquiries about "acceptability and impact of diagnosis" [1] we observed that if a celiac person simultaneously suffers arthrosis, alopecia, diabetes, chronic gastritis and hemorrhoids referred the quality of his/her disease to this condition. At the same time, another person suffering the same conditions without being celiac most probably would refer all of the to his/her bad luck. To find a "quality" or a "justification" of the disease exams from responsibility or protagonism to the patient and he/she may will say or feel that "the problem came from outside". This led us to make this inquiry on celiac disease and the AoC conditions which might influence the healthy/sick feeling of a person.

In this paper we show the impact of the AoC conditions which showed to be highly significant in this feeling, beyond that of the disease itself. Besides we could do some observations.

Celiac people with or without hypothyroidism did not show significant dif- 
ferences as to their feeling of being healthy or sick and their autorating. But this happened in celiacs with or without diabetes. It is obvious that is not the same to have a pill each morning than to measure the glycemia with a puncture and to inject insulin daily. The diabetic often feels that he has a condition that impact in his/her quality of life [2] [3].

Remarkably, people with hypothyroidism develop something similar. In a recent paper about quality of life of people with hypothyroidism it is referred a similarity of their feelings with that of celiacs. Kelderman-Bolk $\mathrm{N}$ et al. say: " $\mathrm{Cu}$ riously, the decrease in the quality of life related with the increase in body weight and that of the body mass index. The overweight is probably a nota taken feature in patients with hypothyroidism, and might be a great contributor to the decrease of the quality of life". Once again an AoC condition, now in people with hypothyroidism, impacts in the quality of life and with that in the feeling of being healthy [4].

The classic sentence in Medicine "There are not diseases but sick persons" is clearly reflected in this inquiry. In the celiacs with just one AoC condition the autorating of " 10 points" was mainly for the celiac with hypothyroidism, and the autorating with "1 point" was in three people, a celiac with gastric ulcer, one with carcinoma and remarkable, also one with hypothyroidism.

In celiacs with only two AoC conditions the autorating with "10 points" was in a person with hypothyroidism and vitíligo (and other AoC conditions) and the autorating with " 1 point" was also in other person with the same combination of AoC conditions. This proves that the sentence referred in the pervious paragraph is real.

The "miscellanea" observations again evidence the impact of the AoC conditions in the feeling of healthy/sick in the celiacs or their relatives. The groups are not different in age however there was a substantial and significant differences between the mothers of celiacs and the celiacs themselves. Many adult celiacs see their lives through the glasses of their AoC conditions. On the contrary the mothers seemed to see the future con optimism due to the medical and social progresses, and always work for a better futures. This was perceived by us since many years ago and was the "materia prima" which led to a change in the Celiac disease in Argentina [5].

A recent paper by Casellas F. et al., done at Barcelona, Spain, shows by using a quality of life test, similar results to those of present paper, and conclusion saying: "When comparing the points of EuroQol-5D among the healthy Spanish population, the values obtained in celiacs in treatment are similar to those observed in the overall population. Celiac disease damages health as perceived by the affected people, but this improves and reaches similar results to those of the general population when treated with a gluten-free diet". [6]

Singularities in the feeding and the appetence and demands

The feeding habits merit a special paragraph. The celiacs are not indifferent to the impact of the milk products publicity but it is remarkable that the energy grains which come to replace the wheat, like maize and rice, and the legumes 
were in the $7^{\text {th }}$ and last place, respectively.

As to the personal wishes "the bread sandwich" which may be interpreted as the "gluten master work", stands first. It will not be easy to find something similar but it is not impossible.

As to what is the celiac expectation from people, it was clear that the lower value in the autorating was that of the group demanding "help", while the higher mean was in the group demanding "nothing".

Finally as related to the State or health systems expectations it is remarkable that in covering and compromise were $79.8 \%$ of the persons, $6.1 \%$ demanded economic help and $5 \%$ wanted nothing.

\section{Comments}

Review, reflections and conclusions

In the seventy decade of the last century, the celiac disease was studied through chemical analysis of nutrients absorption, among the Van de Kamer and D-Xilosa tests, and was recognized due to the worrisome features of the chronic diarrhea, undernutrition and abdominal distention which fully characterized the "Malabsorption syndrome". The condition was defined as a "food intolerance" which completely disappeared with the appropriate diet.

Our working group demonstrated that the small bowel mucosa of celiac children was microscopically indistinguishable from the normal one as to the villous/cripta rate and the quail-quantitative analysis of the different types of cells [7].

In the same paragraph we proposed a mathematic classification in grades of atrophy based on the villous/cripta ratio, a proposal which was then accepted in a pediatric pathologists convention and used without modifications up to this days [8]. Other classifications are under permanent evaluation, modifications or adjustments [9].

There was now a child grossly normal in weight and height and, we could say, also microscopically normal.

Our group also published, for the first time in the World scientific literature, that autoantibodies were present in active celiac disease and that these disappeared with the diet and again increased with food Challenger. So, that these could be used in the follow-up of the treatment and the screening of asymptomatic relatives. Now we could say gross, micro and serologic normal [10] [11].

Along time this condition was left to be a subject of painstakingly analyzed by chemistry through determination of fatty acids and nitrogen in the stools or malabsorption of sugars in blood, to become a model in the research of the immune response and quickly transforming in a "star" in the study of the immunity of the mucosa [12] [13] [14] [15].

It could be said that celiac people are born healthy and that this condition early evidences when a natural food (artificially cultivated and industrialized) is consumed. The archeologists Willeke Wendrich, California University, and Rene Cappers, Gröningen University, say: "Long ago before faraons time, the egip- 
cians raised wheat and barley and raised pigs, goats, lambs and cattle. Some evidences suggested that in that place the agriculture was done more than 7000 years ago. [16]

Today "our everyday bread" is consumed in a very varied way and in an alarming quantities. As the journalist Facundo Sonatt says: "In every morning coast, the pastries at noon or the afternoon bisuitis the wheat is daily present in the menu of the argentines... The consumption of wheat flour was 95 kilos per capita in 2012, according to data or the Federación Argentina de la Industria Molinera" [17].

This consumption induces a heavy damage in predisposed people and generates an immune response which is ineludible and inevitable as the immune response against any injury since nothing that happens to the body is external to immunity

Garrote J. A. et al. say "In susceptible persons the adaptive response, mediated through the activation of antigen-specific lymphocytes, generates a proinflammatory response which ends in an immune-mediates enteropathy characterized by villous atrophy and cripta cell reactive hyperplasia, and the recruit of lymphocytes in the lamina porpia and the epithelium. Besides, some gluten peptides are capable to induce an innate immune response in the gut mucosa. The molecular mechanisms and the cells involved in the early stages of the interaction gluten-gut mucosa are poorly known up to date. There is evidence of a direct toxic effect of gluten peptides in several biologic models. The absence of control of the inflammatory response may be one of the factors underlying the gluten intolerant in these people. The cytokines network implied in celiac disease is characterized by plentiful gamma interferon in the gut mucosa resides the production of several interleukin (IL-15, IL-18 and IL-21). All these mediators are linked to the consumption of gluten and potentiate the local inflammatory response" [12].

\section{ACCEPTANCE OF CELIAC DISEASE}

When speaking of acceptance of the condition it is supposed that the patient has made an introspection to the subject. By doing so the person "catches", "internalises" or understands a "revealed true" about his/her situation which radically his/her position while facing against the treatment. There are many everyday circumstances which lead the celiac person against his/her condition mainly those generating exclusion, and places him/her aside in a group of colleagues. When coming to a group party with his/her gluten-free foodstuff feels that this excludes him/her of the celebration and marks him/her with an uncomfortable class. A logic argument would be that after many years of gluten-free diet the celiac finds such an identification with his/her foodstuff gymnastic that his/her social development passes softly, without troubles. However, it is probable that some personal problem or the smallest logistic inconvenient could stop to get the adequate foodstuff needed at a certain appropriate moment, resulting in a distress reaction or irritability strongly acting upon his/her gluten-intolerance condition [1]. 
One has to admit that the complete acceptability of the celiac condition will happen when the gluten-free foods result easily to get, being accessible, cheaper and tasty like those of general consumption. The absence of adequate food or the difficulty in getting them hurts the personal esteem of the patient and places $\mathrm{him} / \mathrm{her}$ in a second level citizen.

\section{CELIAC DISEASE OR CELIAC SPRUE}

Impact of definitions

In a previous paper we mentioned that most celiac people (596/1000) referred themselves avoiding the word disease and most choosing the word "intolerance", that 294/1000 consider themselves healthy and that only 109/1000 speak of a chronic, incurable disease or tragedy. This would not be a major problem except that the later group speaks on behalf of all and define the rules [1].

The definition proponed by the European Society of Pediatric gastroenterology, Hepatology and Nutrition (ESPGHAN) in 2012 says that it is a systemic immune disorder mediated by gluten and related prolamines, in genetically predisposed people and characterized by a variable combination of clinical manifestations which depends the gluten consumption, specific antibodies, HLA-DQ2 or HLA-DQ8 haplotypes and some degree of small bowel lesion [18].

The Guides of the World Gastroenterology Organization fo Celiac Disease published in April 2012 defines it this way: "Celiac disease is a chronic form of enteropathy resulting from an immune pathogenesis affecting the small bowel of children and adults genetically predisposed; it is triggered by the consumption of food containing gluten which is known as celiac sprue, gluten-sensitive enteropathy or non-tropical sprue" [19].

It is remarkable that a group of highly qualified experts did not take advantage of the opportunity to refer to the "toxic prolamins" and not to "gluten". There are foods containing wheat, oat, barley and rye flours, with its toxic prolamins not as gluten, which is a "later building". For this reason and to express properly is better and more adequate to say "without WOBR" and then to add, if wanted, "gluten free" due to the popularity of the later.

Many pediatricians and pediatric gastroenterologists see the condition with a new tendency to be defined as an "autoimmune, chronic, incurable, multiorganic" disease, to be more a "multisystemic process of autoimmune type associated with a frequent involvement of the digestive tract". This definitively transforms the condition in an entity with negative impact resulting in a prejudice in the labour future of these persons as well as to the access to different health covering systems [20].

We all know that definitions are transitory agreements which frequently changes according to science progresses [18] [19] [20]. An example: There are sports-practicing healthy celiac adults who got along with for more than 30 years with a "food intolerance which disappears with appropriate diet", who suddenly find out, after an experts accordance, that they are suffering "a chronic, incurable, autoimmune and multisystemic" condition.

Our working group is composed mainly by pediatricians and we could not 
stop thinking about the future of absolutely healthy children who will have to "drag" this definition. Our duty is to imagine the future and try to change it for better.

Kurppa K. et al. in a paper entitled "Celiac disease and quality of life as related to health" say: "Along the last decade the Lumber of new studies on the quality of life as related to health in Celiac disease has significantly increased. However, an important limitation of these essays is the use of different type of inquiries and study designs which challenges the comparison of the results. Any way there exists a strong evidence that the quality of life as related to health diminishes in non-treated patients with classic celiac disease. Besides, the benefit of the treatment with a gluten-free diet sustains in the fact that patients adequately performing the treatment seem to have a good quality of life" [21]. Our contribution to his comment is to let it know the impact that the AoC conditions give to the "good or bad quality of life" of this people.

Celic disease has been largely studied as a medical condition and its symptoms and signs widely disseminated as to avoid a late diagnosis and the no-return sequela. Also studied has been the immune response and thoroughly analysed the etiopathogenesis and the absorption. But one cannot stop thinking on the celiac people and their relatives, their feelings and mainly in their future. Our group makes themselves the Pedro Laín Entralgo's (1908-2001) mandate. He said: “The medical doctor must know how to put himself in the other's place, feel like he or she and to be ready as to help when facing difficulties"[22].

There is an anonymous phrase which says; "Time cures all wounds", and another phrase of the philosopher and writer Ludwig Marcase who said: "Time does not cure everything but indeed displaces the incurable from the attention center" [23]. Whichever is the true one it appears clear from present work that most of celiac people felt healthy and as time goes by they felt more healthy and better.

\section{References}

[1] Cueto Rua, E., Guzmán, L., Zubiri, C., Nanfito, G., Urrutia, M. and Mancineli, L. (2014) Aceptability Analysis, Cultural aspects and Personal impact of Diagnosis. In: Rodrigo, L. and Salvador Peña, A., Eds., Celiac Disease and Non-Celiac Gluten Sensitivity, Omni Science, Chapter 20, 407-434. www.omniascience.com

[2] Pham-Short, A., Donaghue, K.C., Ambler, G., Garnett, S. and Craig, M.E. (2016) Quality of Life in Type 1 Diabetes and Celiac Disease: Role of the Gluten-Free Diet. Journal of Pediatrics, 179, 131-138. https://doi.org/10.1016/j.jpeds.2016.08.105

[3] Kalyva, E1, Malakonaki, E., Eiser, C. and Mamoulakis, D. (2011) Health-Related Quality of Life (HRQoL) of Children with Type 1 Diabetes Mellitus (T1DM): Self and Parental Perceptions. Pediatric Diabetes, 12, 34-40. https://doi.org/10.1111/j.1399-5448.2010.00653.x

[4] Kelderman-Bolk, N., Visser, T.J., Tijssen, J.P. and Berghout, A. (2015) Quality of Life in Patients with Primary Hypothyroidism Related to BMI. European Journal of Endocrinology, 173, 507-515. https://doi.org/10.1530/EJE-15-0395

[5] Cueto Rúa, E. and Pecotche, G. (1980) Club de madres de niños celiacos. Su creación. The $207^{\circ}$ Scientific Session, Sociedad Argentina de Pediatría, Filial La Plata, 10 
December 1980. http://www.celiaco.org/index.php/historia

[6] Casellas, F., López Vivancos, J. and Malagelada, J.R. (2005) Perceived Health Status in Celiac Disease. Revista Espanola De Enfermedades Digestivas, 97, 794-804. https://doi.org/10.4321/s1130-01082005001100004

[7] Drut, R. and Cueto Rua, E. (1985) Quantitative and Immunohistochemical Analysis of Jejunal Mucosa in Children with Celiac Disease and with Gluten-Free Diet. Archivos Argentinos de Pediatria, 83, 20-24.

[8] Conclusions of the Session of Diagnosis in Small Bowel Diseases (1986) Hospital Sor María Ludovica Noviembre 2 de 1985. Comité de Gastroenterología de la Sociedad Argentina de Pediatría: Acuerdos y normativas en Clínica, Histopatología y Laboratorio. La Plata. Argentina. Archivos Argentinos de Pediatria, 34, 38-39.

[9] Peña, A.S. (2015) What Is the Best Histopathological Classification for Celiac Disease? Does It Matter? Gastroenterology and Hepatology from Bed to Bench, 8, 239243.

[10] Cueto Rua, E., Menna, M.E., Morales, V.H. and Pecotche, G. (1986) Celiac Disease and Anti-Smooth Muscle Antibodies. Archivos Argentinos de Pediatria, 84, 269273.

[11] Cueto Rua, E., Menna, M.E., Morales, V.H. and Drut, R. (1987) Anti-Smooth Muscle Antibodies in the Recognition and Follow-Up of Celiacs. Acta Gastroenterologica Latinoamericana, 17, 227-234.

[12] Garrote J.A., Gómez-González, E., Bernardo, D., Arranz, E. and Coeliac, C.F. (2008) Disease Pathogenesis: The Proinflammatory Cytokine Network. JPGN, 47, S27-S32. https://doi.org/10.1097/mpg.0b013e3181818fb9

[13] Chirdo, F.G. and Arranz, E. (2013) Celiac Disease: A Very Frequent But Little Known Inmunopathology. Ciencia e Investigación, 63, 57-70.

[14] Abadie, V., Sollid, L.M., Barreiro, L.B. and Jabri, B. (2011) Integration of Genetic and Immunological Insights into a Model of Celiac Disease Pathogenesis. Annual Review of Immunology, 29, 493-525. https://doi.org/10.1146/annurev-immunol-040210-092915

[15] Meresse, B., Malamut, G. and Cerf-Bensussan, N. (2012) Celiac Disease: An Immunological Jigsaw. Immunity, 36, 907-919.

https://doi.org/10.1016/j.immuni.2012.06.006

[16] The Discovery in Egypt of the Oldest Farm (2008). www.lanacion.com.ar

[17] Sonatti, F. (2013) Radiography of Bread Consumption in the Table of Argentine People.

http://www.apertura.com/negocios/Radiografia-del-consumo-del-pan-en-la-mesa-d e-los-argentinos-20130704-0001.html.

[18] Husby, S., Koletzko, S., Korponay-Szabo, I.R., Mearin, M.L., Phillips, A., Shamir, R., Troncone, R., Giersiepen, K., Branski, D., Catassi, C., Lelgeman, M., Mäki, M., Ribes-Koninckx, C., Ventura, A. and Zimmer, K.P. (2012) The ESPGHAN Working Group on Coeliac Disease Diagnosis, on Behalf of the ESPGHAN Gastroenterology Committee. European Society for Pediatric Gastroenterology, Hepatology, and $\mathrm{Nu}$ trition Guidelines for the Diagnosis of Coeliac Disease. JPGN, 54, 136-160.

[19] Ludvigsson, J.F., Leffler, D.A., Bai, J.C., Biagi, F., Fasano, A., Green, P.H, Hadjivassiliou, M., Kaukinen, K., Kelly, C.P., Leonard, J.N., Lundin, K.E., Murray, J.A., Sanders, D.S., Walker, M.M., Zingone, F. and Ciacci, C. (2013) The Oslo Definitions for Coeliac Disease and Related Terms. Gut, 62, 43-52.

https://doi.org/10.1136/gutjnl-2011-301346

[20] Bai, J.C., Ciacci, C., Corazza, G.R., Fried, M., Olano, C., Rostami-Nejad, M., 
González, A., Green, P., Gutierrez-Achury, J., Schultz, M., Verdú, E., Barada, K., Gibson, P., Koletzko, S., Coton, T., Mulder, C., Makharia, G. and LeMair, A. (2016) World Gastroenterology Organisation Global Guidelines Celiac Disease.

[21] Kurppa, K., Collin, P., Mäki, M. and Kaukinen, K. (2011) Celiac Disease and Health-Related Quality of Life. Expert Review of Gastroenterology \& Hepatology, 5, 83-90. https://doi.org/10.1586/egh.10.81

[22] Lain Entralgo, P. (1964) La relación médico enfermo. Madrid: Revista de Occidente.

[23] Marcuse, L. February 8th, 1894, Berlín and August 2nd, 1971. Bad Wiessee.

\section{Scientific Research Publishing}

Submit or recommend next manuscript to SCIRP and we will provide best service for you:

Accepting pre-submission inquiries through Email, Facebook, LinkedIn, Twitter, etc. A wide selection of journals (inclusive of 9 subjects, more than 200 journals)

Providing 24-hour high-quality service

User-friendly online submission system

Fair and swift peer-review system

Efficient typesetting and proofreading procedure

Display of the result of downloads and visits, as well as the number of cited articles

Maximum dissemination of your research work

Submit your manuscript at: http://papersubmission.scirp.org/

Or contact ojepi@scirp.org 